\title{
Human Capital Accounting in Professional Sport: Evidence from Youth Professional Football
}

\author{
Kulikova L.I. \\ Kazan Federal University, Institute of Management, Economics and Finance, Kazan, 420008, Russia \\ Goshunova A.V. \\ Kazan Federal University, Institute of Management, Economics and Finance, Kazan, 420008, Russia \\ Email: anna.goshunova@mail.ru
}

\section{Doi:10.5901/mjss.2014.v5n24p44}

\section{Abstract}

The article comprises a set of theoretical and methodological statements and practical suggestions about the development of youth players' registrations accounting in professional football clubs. Nowadays financial accounting of acquisition costs of professional football players' registrations is well developed and used in practical management of sports organizations. However, accounting for the costs of internally prepared youth players have been neglected. As a result, a substantial share of assets is not adequately reflected in the accounting system and financial reporting of football club. The article proves that investments in youth players meet criteria of asset which is formed over the years in sports academies in the course of trainings and education, and which is capable to generate economic benefits as a part of club's squad.

Keywords: accounting, football, player registration, IFRS, youth academy

\section{Introduction}

Nowadays professional sport became an independent economic industry. Analysis of income structure of European football clubs, conducted according to reports of UEFA "Club licensing benchmarking report financial year 2011" [1] and "Club licensing benchmarking report financial year 2012"[2], shows that source of more than $90 \%$ of income is the main sports club activities (Table 1).

Table 1: Revenue structure of European football clubs

\begin{tabular}{lcccc}
\hline \multirow{2}{*}{ Revenue } & \multicolumn{2}{c}{2011 (235 clubs) } & \multicolumn{2}{c}{2012 (237 clubs) } \\
\cline { 2 - 5 } & in $€$ bn & in \% to the total & in $€$ bn & in \% to the total \\
\hline Sports revenues, including: & 2,6 & 32,91 & 2 & \\
- Broadcasting & 1,3 & 16,46 & 0,9 & 25,00 \\
- UEFA competition prize money & 1,7 & 21,52 & 2 & 11,00 \\
- Sponsorship & 0,3 & 3,80 & 0,8 & 10,00 \\
- Commercial & 1,7 & 21,52 & 1,6 & 20,00 \\
- Gate receipts & 0,3 & 3,80 & 0,8 & 10,00 \\
Other revenues & 7,9 & 100 & 8,1 & 100 \\
Total & & & & \\
\hline
\end{tabular}

Success of sports activity depends primarily on the composition of players which form basis of team. Without talented, highly skilled athletes football club has little chance to attract audiences and and make potential investors, sponsors and advertisers commercially interested in partnership with club.

In this regard, football clubs, annually carrying significant investments in the acquisition of player registrations, aim to improve the quality of game, which promotes the growth of investment attractiveness of club as business unit.

Scales of investment into professional players are comparable on amounts to direct investments in industrial sector.

According to the report «Soccer Transfer Review 2014-Winter window», prepared by the marketing agency «Prime 
Time Sport» in February 2014, at the end of winter transfer window in the season 2012/2013 the total volume of players' transfers from one club to another made by football clubs of five leading Football Associations in Europe (England, Spain, Italy, Germany, France) was estimated at $€ 290$ million [3]. The volume of transactions in the summer transfer window at the same season reached a record volume, having increased compared with the previous period by $40 \%$ and amounted to $€ 2,1$ billion. (Figure 1).

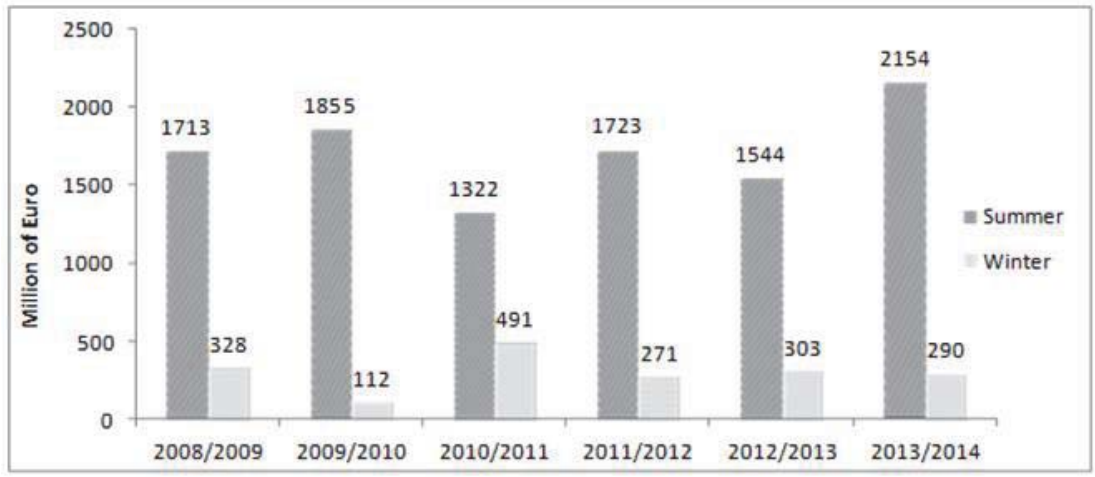

Fig 1. Transfer costs of football clubs from five leading Football Associations (France, Germany, Great Britain, Italy and Spain) in summer and winter transfer window.

Thus, it is obvious that investments in players' registrations are considered as a source of economic benefits which is able to generate cash flow to the sports organization in future.

\section{Accounting for Player Registrations in Professional Football}

Nowadays extensive practice of capitalization of costs on players' registration acquisition as asset with the subsequent reflection in the financial reporting as a part of intangible assets of football clubs is already created.

Analysis of foreign experience has shown that most European football clubs capitalize acquisition costs of players' registrations as intangible assets and reflect them in financial statements. According to the report of UEFA "Club licensing benchmarking report financial year 2010", which characterizes the activity of 665 European football clubs from top divisions, $60 \%$ of European clubs consider costs of players' registrations acquisition as assets and recognize them in the balance sheet [4].

In Great Britain historically costs of purchased players' registrations on terms of transfer contract were considered as current expenses and reflected in profit and loss account. This approach was justified by uncertainty concerning, whether keeping of players registration gave to the club sufficient control over future benefits from the conclusion of the transfer contract [5].

The first club adopted an alternative accounting policy was FC "Tottenham Hotspur". In financial report for the year ended 31 May 1989 it recorded the cost of players' registrations as intangible assets on the balance sheet [6].

Already 18 English clubs applied accounting policy on capitalization of purchased costs of players' registrations as intangible assets by the middle of the 1990th. Book value of such assets consisted of historical acquisition costs minus accumulated depreciation charged during the period of the labor contract signed with football player.

Introduction of national accounting standard FRS 10 'Intangible assets and a goodwill' in December, 1997 significantly changed further accounting practice of English football clubs, demanding from them to follow accounting policy on capitalization of costs of players' registrations as intangible assets and their subsequent depreciation during the period of the labor contract signed with football player [7].

The legal framework regulating Italian professional sport is set out in Law \# 91 of 1981, mentioning the main aspects of financial accounting, taxation and financial activities [8].

The position of the Italian legislators is not fundamentally different from the global practice. Costs of acquiring player registrations are to be recognized as intangible assets, be amortized over the length of player's contract and be reflected as assets on balance sheet [8].

Football clubs "Lazio", "Milan", "Napoli", "Roma", "Juventus", as well as many other Italian football clubs, prepare financial statements on the base of IFRS. According to club's accounting policy costs of purchased players' registrations 
are considered as intangible assets with the certain useful life equal to the length of player's contract with club. Initial value of asset is based on historical costs. Depreciation of such intangible asset is charged by linear method during the length of the contract. Besides, according to the accounting policy in case of long impairment of the rights on player's registration book value is reflected in balance sheet taking into account an impairment loss.

Spain is now moving towards convergence of national accounting standards with IFRS, although it is carried very selectively. The ultimate goal of reform of the Spanish accounting is not total introduction of IAS and IFRS, but rather the adaptation of existing Spanish GAAP. Such adaptations will be ensured by the inclusion of the principles of accounting, which are set by IFRS on a mandatory basis, and where there are discrepancies with IFRS - the choice of the principles which are considered as the most reasonable taking into account Spanish legislative [9].

Long before the beginning of reform of the Spanish accounting system industrial accounting standards were developed for companies of such industries, as construction real estate; sports (sports federations, sports corporations); health care; power industry; wine industry; insurance etc.

Reform of the Spanish accounting requires a revision of the existing industrial standards in order to adapt them to the new accounting principles.

However, no changes still have been made, so that these standards remain in force [9].

Based on the standard for sports corporations, football clubs "Barcelona" and "Real Madrid" capitalize costs on acquisition of players' registrations and other similar payments as intangible assets and amortization them by linear method during the length of contract signed with player. The costs connected with prolongation of the contract, are capitalized in case of asset improvement (which is understood as prolongation of contract length, increase in compensation in case of termination of the contract) and are amortized during the length of new contract. In case of early termination of the contract residual cost is written off.

Thus, world experience shows that nowadays financial accounting of acquisition costs of professional football players' registrations is well developed and used in practical management of sports organizations. Such accounting practice was developed for long years. However, accounting for the costs of internally prepared youth players have been neglected. As a result, a substantial share of assets is not adequately reflected in the accounting system and financial reporting of football club.

\section{Development of Youth Players Registrations' Accounting Policy}

Results of the last Champions League and the World Cup in Brazil in 2014 showed that Germany is deservedly considered as one of the leaders in world football. These achievements are in many respects obliged to the system of training of young athletes which was established in Germany for the purpose of promotion of youth football.

High quality game of the German football players was formed over the years on the base of well organized system of preparation of football players.

After the failure at Euro 2000 German Football Association conducted an analysis of the state of football in the country and concluded that the best German football schools were at the most successful clubs like "Bavaria", "Borussia" and some others. But these schools were not able to fulfill needs in players of whole national football league.

Schools in less elite clubs can't prepare many strong players. Therefore, it is impossible to rely only on clubs in the system of youth preparation. Thus, it became obvious that the national system of training of football players was demanded. As a result the program of development of youth football including construction of national football schools was accepted.

In two years already 390 training centers were constructed. Each school serves 70 clubs which are located nearby. Thus, German Football Association gradually has provided even weak clubs with high-quality young players.

All the children pass careful and constant medical control of regular doctors of the center. Database of all players of the regional centers and national teams is conducted with early age. German Football Association has complete information on talented football players and coaches. As a rule, the first junior German national team is formed from players of the combined regional centers. Football players at the age of 16 years are already invited by professional clubs.

Annually German Football Association spends about € 10 million for this program.

However, football clubs try not to keep up, putting crazy amounts in their academies. According to the report of Bundesliga, 18 clubs of the top division spent about $€ 80$ million for the season-2012/13 for various youth development programs, and since 2001 clubs have already invested in their academies in total € 820 million [10].

It is obvious that investments in youth players are perspective investments with high return in the future. However international accounting practices developed in such a way, that perspective investments couldn't find reflection in a 
financial system of accounting of the company.

According to requirements to the accounting of players registrations, set by UEFA Club Licensing and Financial Fair Play Regulations, despite the fact that football club can obtain some benefit from the use or transfer of players grown in club, in terms of financial accounting expenditures on development and education of home-grown youth players couldn't be reflected in the balance sheet, because only costs of purchased registrations of players are subject of capitalization [11].

Football clubs of Great Britain, Italy and Spain in the accounting policy directly specify impossibility of capitalization of costs associated with education of home-grown players. Such impossibility is proved by provisions of IAS 38 "Intangible Assets" which forbid capitalization for costs of internally generated intangible assets.

Brommer, 2011 [12] explains such accounting dualism pointing out that the value of purchased players registrations can be measured reliably by paid transfer fees for football player contracts, while internally generated youth players registrations fail to have accurate assessment.

Oprean and Oprisor, 2013 [13] agree that youth academy is a very important element for a football club as it assures an ongoing scouting process, it helps lowering medium squad age and it carries the continuity of this sport. The academy's existence is stated in the UEFA licensing regulations as mandatory criterion. Thus, the clubs must have a very well established scouting system, separate youth teams for different age categories, educational programs, qualified personnel, healthcare, management strategy and a development strategy approved by the Licensor.

At the same time Oprean and Oprisor, 2013 [13] highlight that players from the youth academy cannot be recognized as an asset category because they do not meet the criteria of IAS 38. Clubs are not able to provide control over asset due to impossibility to make professional contract with underage player. As a result there is no reliable base for accounting.

Nevertheless, contemporary researchers point out negative effect of accounting policy on ignoring costs of youth football players' registrations.

Lozano and Gallego, 2011 [15] note that football players' transfer rights are the main and core assets in football clubs, but they are partially recognized as assets in accounting. Internally generated players' exploitation rights are not reflected in the balance sheet. Only the acquired players' transfers fees are disclosed but at their historic acquisition cost [15]. Thus, ignoring costs of internally grown player leads to remarkable deviations of market value of club's equity from its book value.

Lozano and Gallego, 2011 [15] show illustration of remarkable cases in which deficit in accounting for youth players' registrations occurs. Most of worldwide famous football players Xavi Hernández, Iniesta, Casillas, Puyol, Piqué, Busquets, J. Navas, F. Llorente, acting in the Spanish national team, the 2010 World Cup Champions in South Africa, the 2012 European Cup Champions, or the multiple winner of the FIFA Golden Ball as the best player in the world Leonel Messi have no accounting value in the balance sheet of their clubs of origin due to their condition of being home-grown players and therefore no transfer fees having been paid when they became part of their clubs' professional squads [17].

This idea finds confirmation in research conducted by Amir and Livne, 2005 [17]. In example of 58 football clubs listed on the London Stock Exchange or the Alternative Investment Market (AIM) for which full financial statements over 1990-2003 were able to be obtained. Using market-based analysis they have found that market values are positively and significantly associated with investment in player contracts.

In our opinion, prohibition for capitalization of costs on home-grown players is fundamentally wrong. The highquality system of training of football players is guarantee of future success of football club. Players of youth teams are the foundation of squad. World experience shows that own youth academy is the most effective way to upgrade the basic structure of club, ensures stability of game and good sports results in the future.

Moreover, availability of youth academy in structure of football club is the mandatory criterion which is to be carried out; otherwise license of UEFA may be cancelled and football club won't be allowed to participate in national and international competitions. Hence, the presence of young players is a prerequisite for future economic benefits, because it gives the club the right to engage in sports activities.

\section{Conclusion}

In other words, costs of training player in youth academy meet the criteria of an asset:

- Result from long-term preparation;

- Able to bring future economic benefits in the form of streams of income from sports activities;

- Controlled by clubs using employment contracts to ensure compliance with the principles of contractual stability, guaranteed by standards regulations of UEFA. 
Consequently, investments in youth players represent an asset which is formed over the years in sports academies in the course of trainings and education, and which is capable to generate economic benefits as a part of club's squad. The impossibility of a reliable assessment of internally generated asset, in our opinion, is excluded in case of organization of a proper analytical accounting within sports academies.

\section{References}

Perry S., Leach S., Maggi M. Club licensing benchmarking report financial year 2011. Switzerland: UEFA, 2011124 p.

Perry S., Leach S., Maggi M. Club licensing benchmarking report financial year 2012. Switzerland: UEFA, 2012124 p.

Soccer Transfer Review 2014-Winter window. Great Britain: Prime Time Sports; 2014 February 78 p.

Perry S., Leach S., Maggi M. Club licensing benchmarking report financial year 2010. Switzerland: UEFA, 2010124 p.

Rowbottom, N., 1998. Intangible asset accounting and accounting policy selection in the football industry, D.S. thesis, The University of Birmingham, Birmingham, Great Britain.

Morrow S. Impression management in football club financial reporting. Working paper, University of Stirling, Scotland.

Financial reporting standard 10 "Goodwill and Intangible Assets". Accounting Standards Board, 1997. London, Great Britain.

Baloncelli A., Caruso R. The organization and economics of Italian serie A: a brief overall view. Rivista Di Diritto Ed Economia Dello Sport, 2011; 7(2): 67-85.

Investinspain.org, 2014. Appendix III Accounting and audit issues: Guide to business in Spain. http://www.investinspain.org/ guidetobusiness/en/11/art_11_0.html (Accessed on July 11, 2014).

Sovsport.ru, 2014. A car of German assembly. http://www.sovsport.ru/gazeta/article-item/726820 (Accessed on July 11, 2014).

UEFA Club Licensing and Financial Fair-Play Regulations - Edition 2012. Switzerland: UEFA, 201287 p.

Brommer B.C. Does the recognition of football players contracts require extra attention? Accounting, Valuation and Duration of Football player contracts. A re-examination with European data. Master thesis Accounting, 2011. Tilburg University, Tilburg, the Netherlands.

Oprean V.-B., Oprisor T. Accounting for soccer players: capitalization paradigm vs. expenditure. Procedia Economics and Finance, 2013; 00. www.sciencedirect.com (Accessed on July 11, 2014).

Hajullina A.D., Romadanova O.A. Technique of measurement of value of the human capital as intangible asset of corporation. Life Science Journal 2014; 11(6s): $518-521$.

Lozano F.J.M., Carrasco Gallego A. Deficits of accounting in the valuation of rights to exploit the performance of professional players in football clubs. A case study. Journal of Management Control, 2011; 22(3): 357-335.

Maksutina E.V., Makarov A.N., Nazmeev E.F., Alpatova E.S. Assessment of economic efficiency of investments into the human capital in modern conditions. Life Science Journal 2014; 11 (6s): 376-379.

Amir E., Livne G. Accounting, valuation and duration of football player contracts. Journal of Business Finance and Accounting, 2005; $32(3) \&(4): 549-586$. 